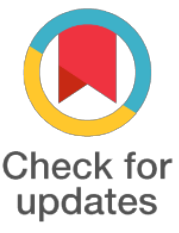

updates

*For correspondence:

yuchen@che.nthu.edu.tw

Competing interests: The authors declare that no competing interests exist.

Received: 2017-05-04

Accepted: 2017-06-15

Published: 2017-09-05

Copyright The Author(s) 2017. This article is published with open access by BioMedPress (BMP).

This article is distributed under the terms of the Creative Commons Attribution License (CC-BY 4.0) which permits any use, distribution, and reproduction in any medium, provided the original author(s) and the source are credited.

\section{RNA Therapeutics and Anabolic Gene Delivery for Tissue Regeneration}

\author{
Yu-Chen $\mathrm{Hu}$
}

Department of Chemical Engineering, National Tsing Hua University, Hsinchu, Taiwan

\begin{abstract}
Regenerative medicine requires coordinated functions of cells, materials and appropriate signaling. Recent years have witnessed the marriage of regenerative medicine and gene delivery by which various genes encoding anabolic/catabolic proteins or RNA therapeutics are delivered into cells to potentiate the tissue regeneration. This presentation will focus on the use of viral vectors for genetic modification of mesenchymal stem cells derived from bone marrow or adipose tissue for tissue regeneration. In particular, emphasis is placed on the applications of baculovirus, an emerging nonpathogenic gene delivery vector, for the delivery of various anabolic genes and miRNA mimics/sponges to repair tissues.
\end{abstract}

Funding

\section{References}

